\title{
The Role of Thiocyanate in Modulating Myeloperoxidase Activity during Disease
}

\author{
Patrick T. San Gabriel ${ }^{1}{ }^{\oplus}$, Yuyang Liu ${ }^{1}{ }^{\oplus}$, Angie L. Schroder ${ }^{1}$, Hans Zoellner ${ }^{2}$ and \\ Belal Chami ${ }^{1,2, *}$ \\ 1 Charles Perkins Centre, Faculty of Medicine and Health, The University of Sydney, Camperdown NSW 2006, \\ Australia; psan7542@uni.sydney.edu.au (P.T.S.G.); anna.liu@sydney.edu.au (Y.L.); \\ asch7719@uni.sydney.edu.au (A.L.S.) \\ 2 Westmead Centre for Oral Health, Sydney Dental School, The University of Sydney, Westmead NSW 2145, \\ Australia; hans.zoellner@sydney.edu.au \\ * Correspondence: belal.chami@sydney.edu.au
}

Received: 1 July 2020; Accepted: 1 September 2020; Published: 3 September 2020

check for updates

\begin{abstract}
Thiocyanate $\left(\mathrm{SCN}^{-}\right)$is a pseudohalide anion omnipresent across mammals and is particularly concentrated in secretions within the oral cavity, digestive tract and airway. Thiocyanate can outcompete chlorine anions and other halides $\left(\mathrm{F}^{-}, \mathrm{Br}^{-}, \mathrm{I}^{-}\right)$as substrates for myeloperoxidase by undergoing two-electron oxidation with hydrogen peroxide. This forms their respective hypohalous acids (HOX where $\mathrm{X}^{-}=$halides) and in the case of thiocyanate, hypothiocyanous acid (HOSCN), which is also a bactericidal oxidative species involved in the regulation of commensal and pathogenic microflora. Disease may dysregulate redox processes and cause imbalances in the oxidative profile, where typically favoured oxidative species, such as hypochlorous acid (HOCl), result in an overabundance of chlorinated protein residues. As such, the pharmacological capacity of thiocyanate has been recently investigated for its ability to modulate myeloperoxidase activity for HOSCN, a less potent species relative to $\mathrm{HOCl}$, although outcomes vary significantly across different disease models. To date, most studies have focused on therapeutic effects in respiratory and cardiovascular animal models. However, we note other conditions such as rheumatic arthritis where $\mathrm{SCN}^{-}$administration may worsen patient outcomes. Here, we discuss the pathophysiological role of $\mathrm{SCN}^{-}$in diseases where MPO is implicated.
\end{abstract}

Keywords: thiocyanate; myeloperoxidase; hypothiocyanous acid; hypochlorous acid

\section{Table of Contents}

1. Introduction

1.1. Sources, Secretion and Elimination of $\mathrm{SCN}^{-}$

1.1.1. Exogenous and Endogenous Sources of $\mathrm{SCN}^{-}$

1.1.2. Secretion and Elimination of $\mathrm{SCN}^{-}$

1.2. Role of $\mathrm{MPO}$ in $\mathrm{SCN}^{-}$Biochemistry

1.3. Halides and the Formation of MPO-mediated Oxidants

2. $\mathrm{SCN}^{-}$in Diseases

2.1. Positive Effect of $\mathrm{SCN}^{-}$in Disease Outcome

2.1.1. Cardiovascular Disease

2.1.2. Respiratory Disease 
Respiratory Viral Infections

2.2. Negative Effect of $\mathrm{SCN}^{-}$in Disease Outcome

2.2.1. Smoking and Respiratory Infections

2.2.2. Autoimmune Rheumatic Diseases

2.2.3. Gastrointestinal Disease

3. Conclusions

\section{Introduction}

\subsection{Sources, Secretion and Elimination of $S C N^{-}$}

\subsubsection{Exogenous and Endogenous Sources of $\mathrm{SCN}^{-}$}

Thiocyanate $\left(\mathrm{SCN}^{-}\right)$is a $58 \mathrm{Da}$ acidic, anionic thiolate molecule that exists in varying concentrations $(0.01-2 \mathrm{mM})$ in secreted biological fluids, blood and urine [1-3]. There is significant variation amongst individuals with regard to $\mathrm{SCN}^{-}$concentrations in physiologic fluids, and this seems due to factors such as diet and smoking habits. Non-smokers have saliva $\mathrm{SCN}^{-}$concentrations of $0.5-2 \mathrm{mM}$, while concentration in smokers average around $3 \mathrm{mM}$, and some smokers may have concentrations as high as $6 \mathrm{mM}$ (Table 1) [4-6]. One report of the $\mathrm{SCN}^{-}$status of U.S. vegetarians and vegans showed that vegans have average urine $\mathrm{SCN}^{-}$levels of $0.01 \mathrm{mM}$, almost double the average urine $\mathrm{SCN}^{-}$levels seen in vegetarians, which was $0.006 \mathrm{mM}$ [7].

Dietary sources of $\mathrm{SCN}^{-}$include glucosidic cyanogen-rich plants such as almonds, cabbage, kale, broccoli, cassava, yam, maize, sugar cane, sorghum and linseed [7,8]. For example, glucobrassicin is a type of glucosinolate concentrated in cruciferous vegetables whereby plant-derived myrosinase (also known as $\beta$-thioglucosidase) mediates the hydrolysis of the glycoside, releasing a glucose and forming the unstable intermediate compound 3-indolylmethyl-isothiocyanate [9]. $\mathrm{SCN}^{-}$is subsequently released at neutral $\mathrm{pH}$ to form the stable product, indole-3-carbinol (Figure 1). Tobacco consumption including occupationally-derived smoke intake also contributes significantly to $\mathrm{SCN}^{-}$levels [10]. Further, $\mathrm{SCN}^{-}$is also generated from Pseudomonas aeruginosa cyanogenesis, an opportunistic pathogen that infects wounds and the lungs of immunocompromised individuals [11].

Although $\mathrm{SCN}^{-}$is mostly acquired from dietary sources, some is produced endogenously as a detoxification product of the reaction between cyanide $\left(\mathrm{CN}^{-}\right)$and thiosulfate $\left(\mathrm{S}_{2} \mathrm{O}_{3}{ }^{2-}\right)$ in the liver $[12,13]$ (Figure 1). The transfer of a sulfur atom between $\mathrm{S}_{2} \mathrm{O}_{3}{ }^{2-}$ and $\mathrm{CN}^{-}$is catalysed by hepatic enzymes, including mitochondrial thiosulfate sulfurtransferase (or rhodanese) and cytosolic mercaptopyruvate sulfurtransferase (Figure 2) [14]. Sulfurtransferases are responsible for $80 \%$ of $\mathrm{CN}^{-}$metabolism [12]. Additionally, oxidation of $\mathrm{SCN}^{-}$into $\mathrm{CN}^{-}$can be mediated by haemoglobin, with the resulting $\mathrm{CN}^{-}$ further detoxified by vitamin $\mathrm{B}_{12}$ (cobalamin) and its precursor cobinamide, before being excreted through the renal system [15-17].

\subsubsection{Secretion and Elimination of $\mathrm{SCN}^{-}$}

Levels of $\mathrm{SCN}^{-}$in the secreted fluid of mammals can vary considerably depending on numerous factors, and can reach up to millimolar concentrations for mucous membranes lining the oral cavity, digestive tract and airway $[18,19]$.

$\mathrm{SCN}^{-}$is secreted by airway, salivary, mammary, lacrimal and gastric glands, and is also present in plasma and urine. Mucosal secretions such as parotid, submandibular and whole saliva, as well as gingival crevicular fluid, dental plaque, nasal airway secretions, tears, gastric fluid and lung airway fluid can have up to approximately $2 \mathrm{mM} \mathrm{SCN}^{-}$, with saliva having the highest levels $[6,18,20]$. Salivary peroxidase and human lactoperoxidase (LPO) are also present in these secretions, and together with other antimicrobial defences in saliva likely account for the high levels of $\mathrm{SCN}^{-}$found $[4,5,21]$. Airway epithelial and nasal lining secretions, on the other hand, have typically lower levels at 
approximately $0.5 \mathrm{mM} \mathrm{SCN}^{-}[18,20]$. Blood plasma, breast milk and urine have $\mathrm{SCN}^{-}$levels 2 to 50 orders of magnitude lower compared with the aforementioned mucosal secretions (Table 1) [21].<smiles>CCCCCCCCCCCCCCCCCCCC(=NOS(=O)(=O)O)SC1OC(CO)C(O)C(O)C1O</smiles>

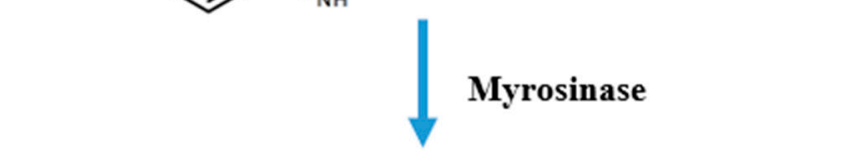<smiles>S=C=NCc1c[nH]c2ccccc12</smiles><smiles>OCC1OC(O)C(O)C(O)C1O</smiles>

Unstable 3-indolylmethyl-isothiocyanate

Glucose

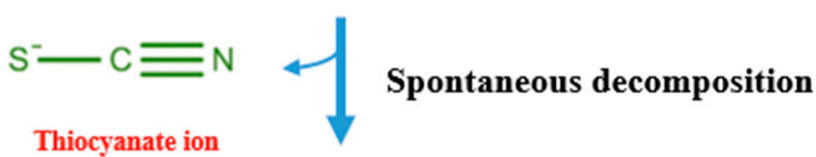<smiles>OCc1c[nH]c2ccccc12</smiles>

Indole-3-carbinol

Figure 1. Exogenous thiocyanate $\left(\mathrm{SCN}^{-}\right)$production from glucosinolates.

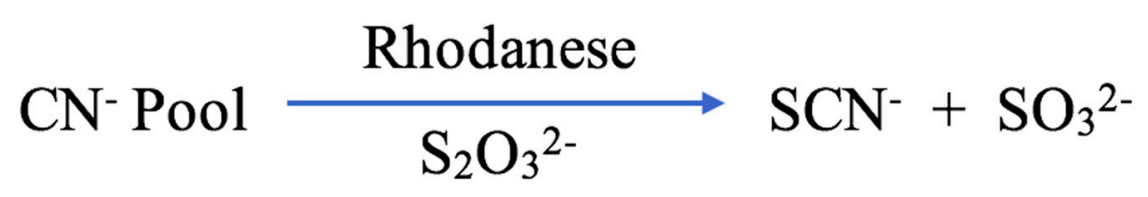

Figure 2. The cyanide detoxification associated endogenous $\mathrm{SCN}^{-}$production pathway [12].

It was proposed that $\mathrm{SCN}^{-}$is concentrated in certain fluids via energy-dependent active transport, and this was initially demonstrated in 1956 by Fletcher et al. [22]. In 1982, Tenovuo et al. showed that stimulating saliva flow rate via expectoration resulted in increased $\mathrm{SCN}^{-}$concentrations when compared with unstimulated saliva collected by drooling, suggesting that $\mathrm{SCN}^{-}$is actively transported in salivary glands to maintain salivary $\mathrm{SCN}^{-}$levels upon increased secretion [23]. Active transport of $\mathrm{SCN}^{-}$into saliva may also provide a recycling mechanism; as saliva is swallowed continuously, 
$\mathrm{SCN}^{-}$would be reabsorbed into the blood by gastrointestinal uptake and concentrated again in salivary glands.

In human bronchial epithelium, $\mathrm{SCN}^{-}$appears to be transported and concentrated via the basolaterally located sodium-iodine symporter (SLC5A5) in a $\mathrm{Na}^{+}$-dependent process [24]. Subsequent secretion at the apical membrane is via several separate mechanisms, including: the cAMP-mediated cystic fibrosis transmembrane conductance regulator (CFTR); purinergic agonists; $\mathrm{Ca}^{2+}$ and interleukin-4 (IL-4) sensitive $\mathrm{Cl}^{-}$channels; the IL-4 sensitive $\mathrm{SCN}^{-} / \mathrm{Cl}^{-}$exchanged pendrin (SLC26A4) [3,24-26].

The half-life of salivary $\mathrm{SCN}^{-}$is reported to be 6-14 days [6,27-30]. While endogenous $\mathrm{SCN}^{-}$does enter the glomerular filtrate, there is $90 \%$ reuptake and this accounts for the low urine $\mathrm{SCN}^{-}$levels found $[7,31]$. Plasma $\mathrm{SCN}^{-}$half-life in healthy individuals is reported to be from 1 to 5 days, and 9 days in individuals with renal insufficiency [31]. Due to its long biological half-life and the significant differences between smoker and non-smoker saliva, plasma and urinary $\mathrm{SCN}^{-}$concentrations have been used as helpful biomarkers for exposure to tobacco or occupational smoke $[6,10]$.

Table 1. Ranges of $\mathrm{SCN}^{-}$concentration in various human biological fluids.

\begin{tabular}{ccccc}
\hline & $\begin{array}{c}\text { Non-Smokers } \\
(\mathbf{m M})\end{array}$ & $\begin{array}{c}\text { Smokers } \\
(\mathbf{m M})\end{array}$ & $\begin{array}{c}\text { Vegan/Vegetarian } \\
(\mathbf{m M})\end{array}$ & References \\
\hline Tears & 0.15 & - & - & {$[32]$} \\
Whole saliva & $0.5-2$ & $2-3.6$ & - & {$[4-6]$} \\
Nasal airway fluids & $1-1.2$ & - & - & {$[33]$} \\
Lung airway fluid & $0.03-0.65$ & - & - & {$[18,20]$} \\
Breastmilk & $0.0001-0.004$ & - & - & {$[34,35]$} \\
Gastric fluids & $0.25-0.3$ & - & - & {$[2]$} \\
Plasma & $0.03-0.05$ & $0.1-0.2$ & - & {$[4,6]$} \\
Urine & $0.009-0.024$ & $0.33-0.275$ & $0.002-0.05 / 0.001-0.034$ & {$[7,10]$} \\
\hline
\end{tabular}

\subsection{Role of $\mathrm{MPO}$ in $\mathrm{SCN}^{-}$Biochemistry}

Myeloperoxidase (MPO) is a heme homodimeric protein $(\sim 146 \mathrm{kDa})$ with functionally independent monomer units consisting of an iron protophorphyrin IX derivative located within the heavy chain of each monomer [36]. The heme unit is located within a deep cleft, restricting access of the iron atom to hydrogen peroxide $\left(\mathrm{H}_{2} \mathrm{O}_{2}\right)$ [37]. Native MPO contains a heme unit within its active site in its ferric $\left(\mathrm{Fe}^{3+}\right)$ form that can undergo a 2-electron oxidation reaction with $\mathrm{H}_{2} \mathrm{O}_{2}$, generating the highly reactive oxy-ferryl $\left(\mathrm{Fe}^{4+}=\mathrm{O}\right)$ heme species containing a porphyrin $\pi$-cation radical [38], also known as Compound 1. MPO Compound 1 is highly reactive and thus can undergo 2-oxidant reduction by halides (e.g., $\mathrm{Cl}^{-}, \mathrm{Br}^{-}$) and pseudohalides (e.g., $\mathrm{SCN}^{-}$) to return to its native $\mathrm{Fe}^{3+}$ form [39]. This pathway is termed the "halogenation cycle", yielding hypochlorous acid $(\mathrm{HOCl})$, hypobromous acid ( $\mathrm{HOBr})$ and hypothiocyanous acid $(\mathrm{HOSCN})$, respectively. Alternatively, Compound 1 can convert back to its native $\mathrm{Fe}^{3+}$ state via an independent pathway involving two sequential one-electron reductions, yielding the intermediate Compound $2\left(\mathrm{Fe}^{4+}=\mathrm{O}\right)$ heme species in a process coined the "peroxidase cycle" [40].

The earliest report on the biological significance of $\mathrm{SCN}^{-}$was in 1814 by German physician Gottfried Reinhold Treviranus, as he discovered a substance in human saliva that produced a blood-red colour when ferric ion was added [21]. In the early to mid-20th century, $\mathrm{SCN}^{-}$had been of particular pharmacologic interest as an oral antihypertensive. Since then, multiple researchers have identified $\mathrm{SCN}^{-}$as a potentially important factor in health and disease.

$\mathrm{SCN}^{-}$plays a vital role as a substrate for human peroxidases, including MPO, LPO, salivary peroxidase, gastric peroxidase, eosinophil peroxidase and thyroid peroxidase [41]. Most of these are present in $\mathrm{SCN}^{-}$-containing extracellular fluids together with $\mathrm{H}_{2} \mathrm{O}_{2}$ [41]. These components act in concert, regulating innate immune processes as well as resident and transient flora [33]. 
It is important to consider the chain of events in inflammatory lesions that lead $\mathrm{SCN}^{-}$to generate the potent bactericidal radical, HOSCN. Nicotinamide adenine dinucleotide phosphate (NADPH) oxidase is a multi-subunit enzyme present in neutrophils and macrophages. In inflammation, activation of $\mathrm{NADPH}$ oxidase catalyses the reaction between oxygen and NADPH, generating superoxide anions, a process that has been coined the "oxidative burst" [42,43]. Superoxide in turn undergoes dismutation, a process through which the anions are simultaneously oxidised and reduced to form $\mathrm{H}_{2} \mathrm{O}_{2}$. Dismutation can occur spontaneously or may be catalysed by the enzyme superoxide dismutase [39]. Lactoperoxidase in secretions, as well as MPO from degranulating leukocytes, catalyse the reaction of $\mathrm{SCN}^{-}$with $\mathrm{H}_{2} \mathrm{O}_{2}$ to produce $\mathrm{HOSCN}$, which is highly effective in killing microbes in these inflammatory environments through its free radical activity (Figure 3) [39].

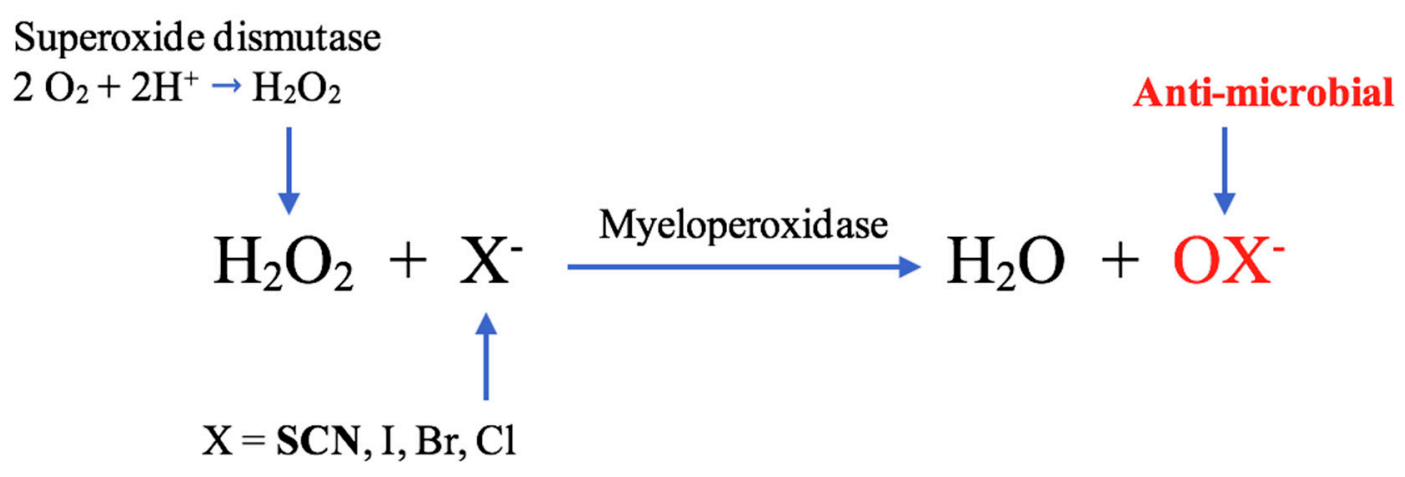

Figure 3. Myeloperoxidase (MPO)-mediated formation of oxidation products, including hypothiocyanous acid (HOSCN), HOI, hypobromous acid (HOBr) and hypochlorous acid (HOCl) [41].

\subsection{Halides and the Formation of MPO-mediated Oxidants}

In addition to $\mathrm{SCN}^{-}$, halide ions (negatively charged halogen atoms) such as $\mathrm{Cl}^{-}$and $\mathrm{Br}^{-}$can also be oxidised into hypohalous acids following reaction with $\mathrm{MPO}$ and $\mathrm{H}_{2} \mathrm{O}_{2}$.

$\mathrm{SCN}^{-}$has a much higher specificity for MPO than $\mathrm{Cl}^{-}$, with specificity constants of 1,60 , and 730 for $\mathrm{Cl}^{-}, \mathrm{Br}^{-}$, and $\mathrm{SCN}^{-}$, respectively, so that $\mathrm{SCN}^{-}$is the preferred substrate for MPO [44]. However, plasma $\mathrm{SCN}^{-}$levels are comparatively very low, with normal halide/pseudohalide ion concentrations in healthy human plasma at $100-140 \mathrm{mM}\left(\mathrm{Cl}^{-}\right), 20-100 \mu \mathrm{M}\left(\mathrm{Br}^{-}\right)$and $200-250 \mu \mathrm{M}\left(\mathrm{SCN}^{-}\right)$[44].

$\mathrm{SCN}^{-}$has potential to become a competitive substrate for MPO when its level is elevated beyond normal plasma level, especially in secretions where $\mathrm{SCN}^{-}$levels are much higher. This is in part due to its faster reaction rate compared with $\mathrm{Cl}^{-}$and $\mathrm{Br}^{-}$[45]. The second-order rate constants for $\mathrm{SCN}^{-}, \mathrm{Cl}^{-}$ and $\mathrm{Br}^{-}$are $9.6 \times 10^{6} \mathrm{M}^{-1} \mathrm{~s}^{-1}, 2.5 \times 10^{4} \mathrm{M}^{-1} \mathrm{~s}^{-1}$ and $1.1 \times 10^{6} \mathrm{M}^{-1} \mathrm{~s}^{-1}$, respectively [46].

Due to the nature and reactivity of different reactive oxygen species (ROS), $\mathrm{HOCl}$ is generally considered as a strong oxidant whilst HOSCN is often classified as a weak oxidant [47]. For example, the second order rate constants against cysteine residues for $\mathrm{HOCl}$ and $\mathrm{HOSCN}$ are $3.6 \times 10^{8} \mathrm{M}^{-1} \mathrm{~s}^{-1}$ and $7.8 \times 10^{4} \mathrm{M}^{-1} \mathrm{~s}^{-1}$, respectively. Similarly, HOSCN oxidises glutathione (GSH) with a second order rate constant considerably lower than $\mathrm{HOCl}$, with values of $2.5 \times 10^{4} \mathrm{M}^{-1} \mathrm{~s}^{-1}$ and $1.2 \times 10^{8} \mathrm{M}^{-1} \mathrm{~s}^{-1}$, respectively $[48,49]$.

\section{2. $\mathrm{SCN}^{-}$in Diseases}

$\mathrm{SCN}^{-}$is an important part of human host defence and health, with pharmacological interest dating back to 1857, where it was investigated for its clinical use as a hypotensive agent [50]. Use in clinical therapies is now restricted, however, due to potential toxic effects. In the 1970s, it was found that concentrations of $\mathrm{SCN}^{-}$in fasting gastric juice specimens from human patients increased the likelihood of nitrosamine production and this was implicated as a potential contributor to gastric 
cancer [51]. Moreover, chronic toxicity of sodium thiocyanate (NaSCN) was demonstrated in the 1980 s in F344 rats, while high serum concentrations of $\mathrm{SCN}^{-}$were associated with lung cancer $[52,53]$. A more recent population-based cross-sectional study found that concentrations of urinary $\mathrm{SCN}^{-}$ were significantly correlated with several diseases including cancer, chronic bronchitis, emphysema, coughing, wheezing and sleep-related conditions [54]. The positive association of $\mathrm{SCN}^{-}$with cancer and lung diseases in a national, population-based study supported previous investigations that utilised smaller and non-representative human sample sizes and those that used animals [54]. Recent research has focused primarily on respiratory and cardiovascular animal models of disease.

We now discuss the roles of $\mathrm{SCN}^{-}$in modulating MPO in disease activity and outcome.

\subsection{Positive Effect of $\mathrm{SCN}^{-}$in Disease Outcome}

\subsubsection{Cardiovascular Disease}

Cardiovascular disease (CVD) is the primary cause of death worldwide, with the majority of CVD deaths related to coronary heart disease (CHD) [55]. CHD is characterised by chronic vascular stenosis and subsequent ischaemic injury/end-organ damage, which is primarily mediated by inflammatory remodelling of the arterial wall [56]. Endothelial dysfunction is the pre-atherosclerotic manifestation associated with invasion of immune cells into the vessel wall and the formation of ROS. It is well documented that MPO is enriched in atherosclerotic plaques and plasma concentration of MPO is a predictive factor in cardiovascular mortality, following angiography in humans [57,58].

The chlorinating activity of MPO is thought to be particularly detrimental during CVD, with high density lipoproteins and low density lipoproteins being vulnerable to oxidation by $\mathrm{HOCl}$ and impairing endothelial function via interference with nitric oxide production [59-61]. $\mathrm{HOCl}$ also induces endothelial apoptosis [62-65]. It was previously reported that pharmacological inhibition of MPO by 4-aminobenzoic acid hydrazide reduces plaque formation in the mouse apolipoprotein $\mathrm{E}$ knockout $\left(\mathrm{ApoE}^{-/-}\right)$model of atherosclerosis [66]. Recently, a new generation of small molecule MPO inhibitors significantly reduced the size of atherosclerotic lesion necrotic cores in $\mathrm{Ldll}^{-/}$mice fed a western diet [67]. Despite the atherosclerotic plaque area remaining similar, MPO inhibition resulted in atherosclerotic plaque stabilisation in this murine model. Conflicting with this study is that an increase in atherosclerosis was observed in $\mathrm{MPO}^{-/-}$mice [68], and this may suggest that MPO-generated reactive intermediates might be protective in murine atherosclerosis, or alternatively microbial involvement following the complete knockout of MPO, a crucial antimicrobial enzyme. The latter possibility is supported by separate work showing pro-atherogenic effects of Porphyromonas gingivalis in mice, rabbits and pigs [69].

High serum levels of $\mathrm{SCN}^{-}$have been shown to improve long-term survival in patients following an acute myocardial infarction [70]. Ironically, smokers who are typically at risk for the early development of CVD have increased blood levels of $\mathrm{SCN}^{-}$[71]. Unlike $\mathrm{HOCl}, \mathrm{HOSCN}$ can be specifically degraded via thioredoxin reductase, thereby reducing its oxidative capacity in vivo [72]. In this way, HOSCN may skew the oxidative profile of MPO, thus reducing oxidative injury of the arterial wall in atherosclerosis. This is consistent with observations in $\mathrm{ApoE}^{-/-}$mice fed a western diet, which have reduced atherosclerotic plaque size following 8 weeks of NaSCN treatment [73]. In this study, serum proinflammatory IL-6 levels were decreased, while IL-10 levels increased with NaSCN treatment, though no effect on monocyte or granulocyte infiltration was observed in the atherosclerotic plaque. Similarly, $\mathrm{SCN}^{-}$supplementation in atherosclerosis-prone $\mathrm{Ldlr}^{-/-}$mice transgenic for human MPO decreased the total plaque area with no changes to serum MPO concentrations between $\mathrm{SCN}^{-}$ supplemented and control mice [44]. Collectively, these studies highlight the therapeutic potential for modulating MPO oxidative activity towards the production of HOSCN in CHD. 


\subsubsection{Respiratory Disease}

$\mathrm{SCN}^{-}$is extensively involved in modulating the oxidative environments of various respiratory diseases, reducing the cytotoxic effect of more powerfully oxidative $\mathrm{HOCl}$. For example, $\mathrm{Xu}$ and colleagues demonstrated the attenuation of MPO cytotoxicity by addition of $\mathrm{SCN}^{-}$to over $100 \mu \mathrm{M}$ in the Calu-3 human lung epithelial, Neuro2a mouse neuroblastoma, human aortic endothelial cells and Min6 mouse pancreatic $\beta$ cell lines [74]. In the same study, dose-dependent inhibition of MPO-produced $\mathrm{OCl}^{-}$ by $\mathrm{SCN}^{-}$was demonstrated, with slight, partial and near complete inhibition achieved using $10 \mu \mathrm{M}$, $50 \mu \mathrm{M}$ and $100-400 \mu \mathrm{M} \mathrm{SCN}^{-}$, respectively [74]. MPO activity in lung tissue has been previously linked to the cessation of ciliary beating $[75,76]$ and damage to airway epithelial cells [77]. Physiologically, ciliary beating functions as a pathogen-clearing mechanism and impaired ciliary beating results in ineffective clearance of pathogenic bacterial species that can promote infection $[75,78]$, contributing to various respiratory disorders including cystic fibrosis (CF).

CFTR is a transmembrane receptor that functions as a chloride channel at the apical membrane of epithelial cells and mutations in CFTR results in the clinical presentation of CF [79]. Interestingly, CFTR also conducts $\mathrm{SCN}^{-}$, as the anion permeability of CFTR for $\mathrm{SCN}^{-}$exceeds that $\mathrm{Cl}^{-}$and the concentration of $\mathrm{SCN}^{-}$in the airway surface liquid is at least $\sim 30$ times its concentration in the serum $[80,81]$. This potentially limits harmful accumulations of $\mathrm{Cl}^{-}$that subsequently form $\mathrm{HOCl}$ in the presence of MPO, while also facilitating the formation of the effective antibacterial compound HOSCN [82]. Unsurprisingly, many researchers have reported a deficiency in the secretion of $\mathrm{SCN}^{-}$in both human CF cells [24,82], as well as human patients [20]. While nebulised hypertonic saline therapy in $\mathrm{CF}$ is reported to improve both $\mathrm{SCN}^{-}$and GSH airway surface liquid levels, a finding which was reproduced in a CFTR knockout animal model [23,83], there are no current clinical trials evaluating nebulised $\mathrm{SCN}^{-}$to date.

CF patients are particularly vulnerable to chronic P. aeruginosa airway infections, where the subsequent inflammatory response contributes to the major clinical problems associated with CF-lung tissue destruction [84]. Recent studies have investigated the anti-inflammatory and anti-bacterial activity of $\mathrm{SCN}^{-}$through the administration of nebulised $\mathrm{SCN}^{-}$in a cystic fibrosis model using beta epithelial sodium channel $(\beta \mathrm{ENaC})$ mice [85]. Compared with wild-type counterparts, $\beta \mathrm{ENaC}$ mice administered $\mathrm{SCN}^{-}$significantly decreased airway neutrophil infiltrate by $68 \%$, and therefore by extrapolation, neutrophil-derived MPO, as well as rebalanced GSH redox ratio in both lung tissue and the lining fluid of airway epithelium [85]. In contrast, there was no significant effect in the reduction in elevated levels of lymphocytes and macrophages in the bronchoalveolar lavage fluid of $\beta \mathrm{ENaC}$ mice by administration of nebulised $\mathrm{SCN}^{-}$. Moreover, $\mathrm{SCN}^{-}$treatment had no effect on other cytokines, including C-X-C motif chemokine ligand 1 , IL-1 $\beta$, TNF- $\alpha$, IFN- $\gamma$, IL-2, IL-4, IL-5, IL-6, IL-10, and IL-12 p70. Levels of the granulocyte oxidative activity biomarker glutathione sulfonamide and glutathione disulfide were also decreased in $\beta \mathrm{ENaC}$ mice [85]. Interestingly, compared with wild-type mice, mean $\mathrm{SCN}^{-}$levels in the epithelial lining fluid were decreased by $60 \%$ in the $\beta \mathrm{ENaC}$ mice that were given vehicle treatment. Thus, the administration of $\mathrm{SCN}^{-}$to $\beta \mathrm{ENaC}$ mice and subsequent reduction in neutrophil infiltrate may be diverting MPO-modulated oxidative activity into another biological compartment.

Both wild-type and $\beta \mathrm{ENaC}$ mice were also infected with P. aeruginosa, where $\mathrm{SCN}^{-}$administration decreased levels of inflammation, bacterial burden, proinflammatory cytokines and 3-nitrotyrosine (only in infected wild-type mice) [85]. Bacterial burden was 70\% less in wild-type mice receiving $\mathrm{SCN}^{-}$as compared with wild-type mice given vehicle treatment. Furthermore, $\beta \mathrm{ENaC}$ mice had an 80-fold increase in bacteria relative to their wild-type counterparts, with $\mathrm{SCN}^{-}$treatment significantly reducing bacterial burden by $92 \%$ [85]. The observed increase in neutrophilic influx after $P$. aeruginos $a$ infection suggests a consequential increase in secreted MPO, and with these data in consideration, may suggest that bacterial burden is ameliorated potentially through the microbicidal action of $\mathrm{MPO} / \mathrm{SCN}^{-}$derived $\mathrm{HOSCN}$. 
Taken together, the evidence suggests a protective role for $\mathrm{SCN}^{-}$in respiratory airways, where $\mathrm{SCN}^{-}$ supplementation may provide a therapeutic effect in patients with CF. The anti-inflammatory action of $\mathrm{SCN}^{-}$may potentially be attributed to a decrease in bacterial burden, as well as in the mitigation of neutrophilic infiltration, thereby diverting MPO-mediated damage away from pulmonary tissue.

\section{Respiratory Viral Infections}

In addition to its antibacterial activity that combats respiratory infections, $\mathrm{SCN}^{-}$, as well as hypothiocyanite $\left(\mathrm{OSCN}^{-}\right)$, the conjugate base of $\mathrm{HOSCN}$, holds antiviral effects that have been investigated in various in vitro influenza viral systems. $\mathrm{OSCN}^{-}$virucidal activity against the A/H1N1 2009 pandemic influenza virus has been demonstrated in vitro. Specifically, a dose-dependent effect without cytotoxicity was observed where $2 \mu \mathrm{M} \mathrm{OSCN}^{-}$administered achieved inhibition of viral replication by $50 \%$ prior to cell inoculation [86]. Moreover, the $\mathrm{LPO} / \mathrm{H}_{2} \mathrm{O}_{2} / \mathrm{SCN}^{-}$system has been shown to inactivate the A/Swine/02860/2009 influenza A strain virus within both differentiated rat and human tracheobronchial epithelial cells [87], and in a cell-free system [88]. Increased production of mucin and dual oxidase expression was demonstrated in the former model associated with inactivation of the influenza A virus, whilst the latter model displayed inactivation of the influenza $\mathrm{A}$ virus strains, including H1N1, H1N2, H3N2, and the influenza B viruses of Yamagata and Victoria lineages, though the extent of this inactivation varied between the influenza strain and LPO substrate $\left(\mathrm{SCN}^{-}\right.$or $\left.\mathrm{I}^{-}\right)$[88]. Nevertheless, it appears that the antiviral capabilities of $\mathrm{SCN}^{-}$and its chemical analogues working through the $\mathrm{LPO} / \mathrm{H}_{2} \mathrm{O}_{2} / \mathrm{SCN}^{-}$system are beneficially implicated in inactivating numerous influenza virus strains in vitro. In light of the current global pandemic featuring the novel severe acute respiratory syndrome coronavirus 2 (SARS-CoV-2), investigating the effects of $\mathrm{SCN}^{-}$on SARS-CoV-2 in vitro and perhaps in animal models, may be a potential avenue for further research.

\subsection{Negative Effect of $\mathrm{SCN}^{-}$in Disease Outcome}

\subsubsection{Smoking and Respiratory Infections}

As tobacco smoking increases $\mathrm{SCN}^{-}$levels considerably in the mucosa, one may assume that tobacco smoke can elicit antimicrobial effects; however, a plethora of evidence exists demonstrating that cigarette smoking exacerbates respiratory infections. For example, both passive and active smoking are significant risks for the development of upper respiratory tract infections, particularly otitis media [89-91] and for the colonisation of Streptococcus pneumoniae within the nasopharynx for both children and adults [92]. Furthermore, an examination of several systematic reviews and meta-analyses found that smokers are twice as likely to contract Mycobacterium tuberculosis infections, resulting in the development of, and death from, active tuberculosis, though interpretation may be affected due to differences in data from these studies [93-95]. The correlation between increased risk for the development of tuberculosis and cigarette smoke has been reported in various countries including India [96], China [97], South Africa [98] and Mexico [99]. Additionally, cigarette smoking increases the frequency of obtaining community-acquired pneumonia by approximately twofold [100] and in immunocompetent non-elderly adults, smoking is the top independent risk factor for invasive pneumococcal disease [101].

Profound changes in mucous production mechanisms and airway epithelial metaplastic changes can instead explain the increased susceptibility of smokers to respiratory infections. Squamous metaplasia of respiratory epithelium is common in habitual smokers, where specialised bronchial ciliated columnar epithelia is replaced with stratified squamous epithelia [102]. This adaptive mechanism provides a physical barrier against noxious chemicals in cigarette smoke but compromises normal ciliary function and thereby impacts the drainage of secretory products via mucociliary transport. The toxic metabolite of nicotine is also capable of significantly reducing the ciliary beat of epithelial cells as demonstrated in an in vitro model [103]. In addition, cigarette smoke increases the number and size of goblet cells in the respiratory mucosa, resulting in increased airway secretions [104]. 
Increased respiratory airway secretions coupled with reduced mucociliary transport is thought to increase the risk of respiratory infections, offsetting the benefit increased $\mathrm{SCN}^{-}$may offer.

\subsubsection{Autoimmune Rheumatic Diseases}

Rheumatoid arthritis (RA) is a T-cell and autoantibody-mediated autoimmune disease which results in joint damage and destruction of cartilage. Neutrophils are prominent in the pathogenesis of RA, as demonstrated in numerous RA mouse models as well as human disease [105]. In two prominent mouse models of RA, namely $\mathrm{K} / \mathrm{BxN}$ antibody-mediated arthritis and collagen-induced arthritis, a specific role for MPO was indicated by reduced disease severity in $\mathrm{MPO}^{-/-}$mice [106-109]. Supporting a role for MPO in human disease, the enzyme is found in both intracellular and extracellular locations in the synovium of RA patients [110]. Furthermore, levels of the MPO-mediated specific oxidation product of $\mathrm{HOCl}$, 3-chlorotyrosine (3-Cl-Tyr), are significantly higher in synovial fluids of RA patients compared with those from patients with osteoarthritis [110]. Neutrophils from RA patients spontaneously generate neutrophil extracellular traps ex vivo, which are associated with MPO release and this suggests a role for leukocyte priming [111].

Destruction of cartilage, but not bone, is largely attributed to matrix metalloproteinase (MMP) activity in RA [112]. Several MMPs are implicated in the pathogenesis of RA, including MMP-1, MMP-2, MMP-3, MMP-8, MMP-9, MMP-10, MMP-12 and MMP-13, and these degrade a broad range of matrix components [112]. MMPs are produced as inactive pro-forms which require either serine-protease cleavage of an inhibitory pro-peptide domain, or oxidation of the critical thiol cysteine residue, while both scenarios expose the catalytically active $\mathrm{Zn}^{2+}$ site [113]. The MPO oxidation product $\mathrm{HOCl}$ has previously been shown to activate MMP-7 by oxidation of the key cysteine residue to a sulfinic acid form [114]. While $\mathrm{HOCl}$ is a relatively promiscuous oxidant, $\mathrm{HOSCN}$ is less reactive and highly selective for thiol sites, which represent the major site of reaction $[49,115]$. Therefore, it is plausible that skewing the oxidative profile of MPO from $\mathrm{HOCl}$ to $\mathrm{HOSCN}$ can result in increased oxidation of catalytic $\mathrm{Zn}^{2+}$ sites of pro-MMPs, increasing the overall activity of MMPs. Although the respective roles of HOSCN and MMP are not fully elucidated, it is well established that cigarette smoke and the associated increase in serum $\mathrm{SCN}^{-}$is linked with increased severity and incidence of RA, and that this results in increased intensity and duration of disease, so that fewer smoking patients enter full remission [116]. In a rat model of experimental arthritis, sodium/potassium $\mathrm{SCN}^{-}$ was supplemented to mimic elevated levels of $\mathrm{SCN}^{-}$in the blood, saliva, and urine of smokers [117]. Rats supplemented with $\mathrm{SCN}^{-}$showed pro-arthritic and proinflammatory changes when subjected to various arthritic-inducing agents.

Carbamylation is a non-enzymatic post-translational modification, whereby amine or thiol groups transform into carbamyl groups via the presence of increased cyanate $\left(\mathrm{OCN}^{-}\right)$[118]. $\mathrm{OCN}^{-}$forms a natural homeostatic equilibrium in physiological systems, where $\mathrm{OCN}^{-}$concentration is too low to allow extensive carbamylation of protein. However, several environmental factors, such as smoking, cause a pathophysiological increase in $\mathrm{OCN}^{-}$. Increased $\mathrm{SCN}^{-}$levels from cigarette smoke drive MPO Compound 1-mediated competitive oxidation of $\mathrm{SCN}^{-}$to $\mathrm{HOSCN}$ and, to a lesser extent, $\mathrm{OCN}^{-}[71,119,120]$. The conversion of lysine to homocitrulline is the most commonly described carbamylation process, and recently a new autoantibody system has been described in RA. Autoantibodies against proteins that contain homocitrulline residues (anti-carbamylated protein antibodies) are present in a subset of RA patients and can be independent from anti-citrullinated protein antibodies $[119,121]$. Interestingly, the presence of anti-carbamylated protein antibodies in RA patients is associated with more severe joint damage compared with patients who are negative for anti-citrullinated protein antibodies [122].

From the above, the evidence suggests that $\mathrm{SCN}^{-}$is pro-arthritic via the potential pathway for MPO-derived HOSCN to activate pro-MMP at synovial sites, or the MPO/HOSCN-mediated increase in local $\mathrm{OCN}^{-}$levels, increasing overall carbamylation of local proteins. 


\subsubsection{Gastrointestinal Disease}

Two main conditions drive inflammatory bowel disease (IBD) where there is chronic inflammation in the gut: ulcerative colitis (UC) and Crohn's disease. A chronic influx of leukocytes into the gut mucosa is a major pathological presentation in IBD, which is thought to result from an abnormal host immune response to otherwise harmless commensal flora [123]. In the context of UC, the extent of neutrophil infiltration correlates with the severity of disease and is incorporated into the clinical UC severity scoring method [124]. Moreover, neutrophil depletion in rodents ameliorates experimental colitis [125,126]. Further, we earlier demonstrated a role for neutrophil-derived MPO in murine experimental colitis, with significant attenuation of disease via pharmacological inhibition of MPO [127].

It is increasingly recognised that ROS generated during inflammation plays a significant role in prolonging gastrointestinal inflammatory cycles and causing gastrointestinal injury. Colonic and faecal MPO, present in polymorphonuclear leukocytes, are significantly increased and correlate with disease severity in UC patients [128,129]. MPO is a primary source of potent ROS, including hypohalous acids $\mathrm{HOCl}, \mathrm{HOSCN}$ and $\mathrm{HOBr}$ in the inflamed colon $[130,131]$. However, the proportion of MPO-oxidants formed during UC or Crohn's disease is yet to be assessed. Despite this, 3-Cl-Tyr, a HOCl-specific biomarker, is significantly increased in colonic and serum samples of IBD patients [132].

Interestingly, active smokers who have significantly higher $\mathrm{SCN}^{-}$concentrations in body fluids also exhibit reduced risk (1.7-fold) against UC and protection from the clinical symptoms including reduced flares, less need for steroids and a lower colectomy rate [133]. Thus, we speculated that $\mathrm{SCN}^{-}$supplementation would confer protection during experimental colitis by redirection of MPO halogenation to favour HOSCN production above HOCl.

In our recent study, mice were supplemented with NaSCN to closely match levels in human smokers [134] before being subjected to colitis in a 3\% (w/v) dextran sodium sulfate (DSS) colitis model [135]. We observed increased faecal and serum $\mathrm{SCN}^{-}$levels in $\mathrm{NaSCN}$-supplemented mice to above $\mathrm{IC}_{50}$ inhibition levels of $\mathrm{MPO} / \mathrm{HOCl}$, as determined by $\mathrm{HOCl}$-mediated oxidation of luminol. Notably, 3-Cl-Tyr was found to be comparatively lower in colonic samples of $\mathrm{SCN}^{-}$-supplemented DSS mice. This indicated a reduction in the production of $\mathrm{HOCl}$, potentially diverging MPO oxidation production to $\mathrm{HOSCN}$ by increased presence of free $\mathrm{SCN}^{-}$ions.

However, NaSCN supplementation did not attenuate the course of experimental murine colitis. No data were collected on mouse activity levels, colon lengths, or colonic histopathology in the $\mathrm{SCN}^{-}$-supplemented groups. Interestingly, mice supplemented with $\mathrm{DSS} / \mathrm{SCN}^{-}$showed marked upregulation in thiol synthesis markers Nrf2 and GCLC, indicating that thiol synthesis was enhanced in this group of mice and may provide an increase in antioxidant status for the colon during DSS-insult. Overall, increasing $\mathrm{SCN}^{-}$in the gut and circulation provided minimal protection against active experimental colitis.

\section{Conclusions}

$\mathrm{SCN}^{-}$supplementation has been investigated in various disease models (Figure 4). Notably, in respiratory and cardiovascular disease, $\mathrm{SCN}^{-}$appears to be protective against disease via direct modulation of MPO activity, favouring the production of the HOSCN oxidant. On the other hand, $\mathrm{SCN}^{-}$seems to be implicated in the pathogenesis of rheumatic arthritis, while there is limited evidence to support a role in IBD. Irrespective of any possible direct roles for MPO in pathogenic mechanisms, the potential therapeutic value of $\mathrm{SCN}^{-}$must be carefully considered in the context of each specific clinical condition. 


\section{Cardiovascular Disease}

- long term survival post myocardial infarction

- $\downarrow$ atherosclerotic plaque size

- stabilisation of atherosclerotic

plaques via reduced oxidative activity of $\mathrm{SCN}^{-}$resulting in lower rate of endothelial apoptosis

\section{Gastrointestinal Disease}

- $\downarrow$ risk and severity of $\mathrm{CD} / \mathrm{UC}$

- $\uparrow$ thiol synthesis/ endogenous antioxidant capacity

- $\downarrow$ faecal levels of 3-Cl-Tyr

\section{Thiocyanate}

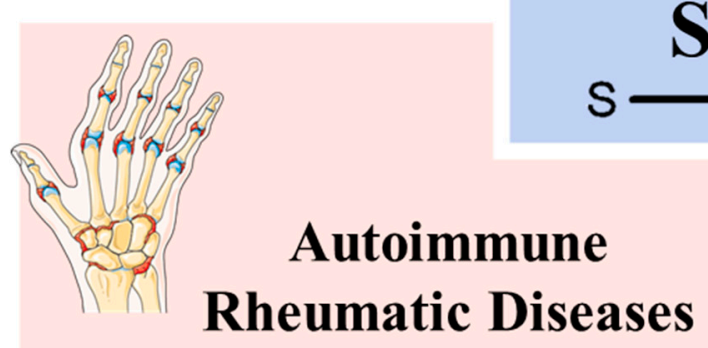

- $\uparrow$ risk and severity of RA

- $\uparrow$ carbamylation of proteins

-Subset of RA patients produce anti-CarP antibodies

- $\uparrow$ activation of pro-MMP in synovial joints

\section{Respiratory}

\section{Disease}

$\bullet \downarrow$ oxidative damage of airway

epithelium/cilia

$\bullet \downarrow \mathrm{HOCl}$ damage via CFTR

mediated apical accumulation of

$\mathrm{SCN}^{-}$in airway lumen

- $\downarrow$ bacterial burden and neutrophil

infiltration during infection

Figure 4. Schematic overview of $\mathrm{SCN}^{-}$in various human diseases.

Author Contributions: B.C. was responsible for the conceptualization of this review and has contributed significantly to many sections, notably $\mathrm{SCN}^{-}$in disease. P.T.S.G. reviewed the literature and compiled the introduction (along with Y.L.) and diseases section. A.L.S. developed all schematic diagrams and H.Z. provided a substantive review and editing. All authors have read and agreed to the published version of the manuscript.

Funding: This research received no external funding.

Conflicts of Interest: The authors declare no conflict of interest.

$\begin{array}{ll}\text { Abbreviations } \\ \text { 3-Cl-Tyr } & \text { 3-chlorotyrosine } \\ \text { ApoE } & \text { Apolipoprotein E Knockout } \\ \beta E N a C & \text { Beta Epithelial Sodium Channel } \\ \text { CF } & \text { Cystic Fibrosis } \\ \text { CFTR } & \text { Cystic Fibrosis Transmembrane Conductance Regulator } \\ \mathrm{CN}^{-} & \text {Cyanide Ion } \\ \text { DSS } & \text { Dextran Sodium Sulfate }\end{array}$




$\begin{array}{ll}\mathrm{GSH} & \text { Glutathione } \\ \mathrm{H}_{2} \mathrm{O}_{2} & \text { Hydrogen Peroxide } \\ \mathrm{HOBr} & \text { Hypobromous Acid } \\ \mathrm{HOCl} & \text { Hypochlorous Acid } \\ \mathrm{HOSCN} & \text { Hypothiocyanous Acid } \\ \mathrm{IBD} & \text { Inflammatory Bowel Disease } \\ \mathrm{IL}-4 & \text { Interleukin-4 } \\ \mathrm{LPO} & \text { Lactoperoxidase } \\ \mathrm{MMP} & \text { Matrix Metalloproteinase } \\ \mathrm{MPO} & \text { Myeloperoxidase } \\ \mathrm{NADPH} & \text { Nicotinamide Adenine Dinucleotide Phosphate } \\ \mathrm{NaSCN} & \text { Sodium Thiocyanate } \\ \mathrm{OCN} & \text { Cyanate Ion } \\ \mathrm{OSCN}^{-} & \text {Hypothiocyanite Ion } \\ \mathrm{RA}^{-} & \text {Rheumatoid Arthritis } \\ \mathrm{ROS}_{\mathrm{S}_{2} \mathrm{O}_{3}{ }^{2-}} & \text { Reactive Oxygen Species } \\ \mathrm{SARS}^{-\mathrm{CoV}}-2 & \text { Thiosulfate Ion } \\ \mathrm{SCN}^{-} & \text {Severe Acute Respiratory Syndrome Coronavirus 2 } \\ \mathrm{UC} & \text { Thiocyanate Ion }\end{array}$

\section{References}

1. Thomas, E.L. Lactoperoxidase-catalyzed oxidation of thiocyanate: Equilibria between oxidized forms of thiocyanate. Biochemistry 1981, 20, 3273-3280. [CrossRef] [PubMed]

2. Das, D.; De, P.K.; Banerjee, R.K. Thiocyanate, a plausible physiological electron donor of gastric peroxidase. Biochem. J. 1995, 305 Pt 1, 59-64. [CrossRef]

3. Fragoso, M.A.; Fernandez, V.; Forteza, R.; Randell, S.H.; Salathe, M.; Conner, G.E. Transcellular thiocyanate transport by human airway epithelia. J. Physiol. 2004, 561, 183-194. [CrossRef] [PubMed]

4. Schultz, C.P.; Ahmed, M.K.; Dawes, C.; Mantsch, H.H. Thiocyanate levels in human saliva: Quantitation by Fourier transform infrared spectroscopy. Anal. Biochem. 1996, 240, 7-12. [CrossRef] [PubMed]

5. Minarowski, L.; Sands, D.; Minarowska, A.; Karwowska, A.; Sulewska, A.; Gacko, M.; Chyczewska, E. Thiocyanate concentration in saliva of cystic fibrosis patients. Folia Histochem. Cytobiol. 2008, 46, 245-246. [CrossRef]

6. Madiyal, A.; Ajila, V.; Babu, S.G.; Hegde, S.; Kumari, S.; Madi, M.; Achalli, S.; Alva, P.; Ullal, H. Status of thiocyanate levels in the serum and saliva of non-smokers, ex-smokers and smokers. Afr. Health Sci. 2018, 18, 727-736. [CrossRef]

7. Leung, A.M.; Lamar, A.; He, X.; Braverman, L.E.; Pearce, E.N. Iodine status and thyroid function of Boston-area vegetarians and vegans. J. Clin. Endocrinol. Metab. 2011, 96, E1303-E1307. [CrossRef]

8. Han, H.; Kwon, H. Estimated dietary intake of thiocyanate from Brassicaceae family in Korean diet. J. Toxicol. Envrion. Health A 2009, 72, 1380-1387. [CrossRef]

9. McGregor, D.I. Thiocyanate ion, a hydrolysis product of glucosinolates from rape and mustard seed. Can. J. Plant Sci. 1978, 58, 795-800. [CrossRef]

10. Buratti, M.; Xaiz, D.; Caravelliand, G.; Colombi, A. Validation of urinary thiocyanate as a biomarker of tobacco smoking. Biomarkers 1997, 2, 81-85. [CrossRef]

11. Lenney, W.; Gilchrist, F.J. Pseudomonas aeruginosa and cyanide production. Eur. Respir. J. 2011, $37,482$. [CrossRef] [PubMed]

12. Nagahara, N.; Okazaki, T.; Nishino, T. Cytosolic mercaptopyruvate sulfurtransferase is evolutionarily related to mitochondrial rhodanese. Striking similarity in active site amino acid sequence and the increase in the mercaptopyruvate sulfurtransferase activity of rhodanese by site-directed mutagenesis. J. Biol. Chem. 1995, 270, 16230-16235. [CrossRef]

13. Wrobel, M.; Jurkowska, H.; Sliwa, L.; Srebro, Z. Sulfurtransferases and cyanide detoxification in mouse liver, kidney, and brain. Toxicol. Mech. Methods 2004, 14, 331-337. [CrossRef] [PubMed] 
14. Weuffen, W.; Franzke, C.; Thurkow, B. The alimentary ingestion, analysis and biological significance of thiocyanate. Nahrung 1984, 28, 341-355. [CrossRef]

15. Chung, J.; Wood, J.L. Oxidation of Thiocyanate to Cyanide Catalyzed by Hemoglobin. J. Biol. Chem. 1971, 246, 555-560. [PubMed]

16. Wells, D.G.; Langman, M.J.; Wilson, J. Thiocyanate metabolism in human vitamin B12 deficiency. Br. Med. J. 1972, 4, 588-590. [CrossRef] [PubMed]

17. Broderick, K.E.; Potluri, P.; Zhuang, S.; Scheffler, I.E.; Sharma, V.S.; Pilz, R.B.; Boss, G.R. Cyanide detoxification by the cobalamin precursor cobinamide. Exp. Biol. Med. 2006, 231, 641-649. [CrossRef]

18. Thomson, E.; Brennan, S.; Senthilmohan, R.; Gangell, C.L.; Chapman, A.L.; Sly, P.D.; Kettle, A.J.; Balding, E.; Berry, L.J.; Carlin, J.B.; et al. Identifying peroxidases and their oxidants in the early pathology of cystic fibrosis. Free Radic. Biol. Med. 2010, 49, 1354-1360. [CrossRef]

19. Chandler, J.D.; Day, B.J. Biochemical mechanisms and therapeutic potential of pseudohalide thiocyanate in human health. Free Radic. Res. 2015, 49, 695-710. [CrossRef]

20. Wijkstrom-Frei, C.; El-Chemaly, S.; Ali-Rachedi, R.; Gerson, C.; Cobas, M.A.; Forteza, R.; Salathe, M.; Conner, G.E. Lactoperoxidase and human airway host defense. Am. J. Respir. Cell Mol. Biol. 2003, 29, 206-212. [CrossRef]

21. Ashby, M. Hypothiocyanite. Adv. Inorg. Chem. 2012, 64, 263-303. [CrossRef]

22. Fletcher, K.; Honour, A.J.; Rowlands, E.N. Studies on the concentration of radioiodide and thiocyanate by slices of the salivary gland. Biochem. J. 1956, 63, 194-199. [CrossRef] [PubMed]

23. Tenovuo, J.; Pruitt, K.M.; Thomas, E.L. Peroxidase antimicrobial system of human saliva: Hypothiocyanite levels in resting and stimulated saliva. J. Dent. Res. 1982, 61, 982-985. [CrossRef] [PubMed]

24. Pedemonte, N.; Caci, E.; Sondo, E.; Caputo, A.; Rhoden, K.; Pfeffer, U.; Di Candia, M.; Bandettini, R.; Ravazzolo, R.; Zegarra-Moran, O.; et al. Thiocyanate transport in resting and IL-4-stimulated human bronchial epithelial cells: Role of pendrin and anion channels. J. Immunol. 2007, 178, 5144-5153. [CrossRef] [PubMed]

25. Moskwa, P.; Lorentzen, D.; Excoffon, K.J.; Zabner, J.; McCray, P.B., Jr.; Nauseef, W.M.; Dupuy, C.; Banfi, B. A novel host defense system of airways is defective in cystic fibrosis. Am. J. Respir. Crit. Care Med. 2007, 175, 174-183. [CrossRef] [PubMed]

26. Gould, N.S.; Gauthier, S.; Kariya, C.T.; Min, E.; Huang, J.; Brian, D.J. Hypertonic saline increases lung epithelial lining fluid glutathione and thiocyanate: Two protective CFTR-dependent thiols against oxidative injury. Respir. Res. 2010, 11, 119. [CrossRef]

27. Pettigrew, A.R.; Fell, G.S. Simplified colorimetric determination of thiocyanate in biological fluids, and its application to investigation of the toxic amblyopias. Clin. Chem. 1972, 18, 996-1000. [CrossRef]

28. Tenovuo, J.; Makinen, K.K. Concentration of thiocyanate and ionizable iodine in saliva of smokers and nonsmokers. J. Dent. Res. 1976, 55, 661-663. [CrossRef]

29. Junge, B. Changes in serum thiocyanate concentration on stopping smoking. Br. Med. J. 1985, 291, 22. [CrossRef]

30. Kalburgi, C.V.; Naik, K.L.; Kokatnur, M.V.; Warad, S. Estimation and correlation of salivary thiocyanate levels in healthy and different forms of tobacco users having chronic periodontitis: A cross-sectional biochemical study. Contemp. Clin. Dent. 2014, 5, 182-186. [CrossRef]

31. Schulz, V.; Bonn, R.; Kindler, J. Kinetics of elimination of thiocyanate in 7 healthy subjects and in 8 subjects with renal failure. Klin. Wochenschr. 1979, 57, 243-247. [CrossRef] [PubMed]

32. van Haeringen, N.J.; Ensink, F.T.; Glasius, E. The peroxidase-thiocyanate-hydrogenperoxide system in tear fluid and saliva of different species. Exp. Eye Res. 1979, 28, 343-347. [CrossRef]

33. Lorentzen, D.; Durairaj, L.; Pezzulo, A.A.; Nakano, Y.; Launspach, J.; Stoltz, D.A.; Zamba, G.; McCray, P.B., Jr.; Zabner, J.; Welsh, M.J.; et al. Concentration of the antibacterial precursor thiocyanate in cystic fibrosis airway secretions. Free Radic. Biol. Med. 2011, 50, 1144-1150. [CrossRef] [PubMed]

34. Wokes, F.; Wedgwood, P.; Wyatt, J. Thiocyanates in milk and other biological fluids. Biochem. J. 1952, 50, xix-xx.

35. Kirk, A.B.; Dyke, J.V.; Martin, C.F.; Dasgupta, P.K. Temporal patterns in perchlorate, thiocyanate, and iodide excretion in human milk. Environ. Health Perspect. 2007, 115, 182-186. [CrossRef]

36. Fiedler, T.J.; Davey, C.A.; Fenna, R.E. X-ray crystal structure and characterization of halide-binding sites of human myeloperoxidase at 1.8 A resolution. J. Biol. Chem. 2000, 275, 11964-11971. [CrossRef]

37. Zeng, J.; Fenna, R.E. X-ray crystal structure of canine myeloperoxidase at 3 Å resolution. J. Mol. Biol. 1992, 226, 185-207. [CrossRef] 
38. Dolphin, D.; Forman, A.; Borg, D.C.; Fajer, J.; Felton, R.H. Compounds I of catalase and horse radish peroxidase: Pi-cation radicals. Proc. Natl. Acad. Sci. USA 1971, 68, 614-618. [CrossRef]

39. Vlasova, I.I. Peroxidase Activity of Human Hemoproteins: Keeping the Fire under Control. Molecules 2018, 23, 2561. [CrossRef]

40. Kettle, A.J.; Anderson, R.F.; Hampton, M.B.; Winterbourn, C.C. Reactions of superoxide with myeloperoxidase. Biochemistry 2007, 46, 4888-4897. [CrossRef]

41. Chandler, J.D.; Day, B.J. Thiocyanate: A potentially useful therapeutic agent with host defense and antioxidant properties. Biochem. Pharmacol. 2012, 84, 1381-1387. [CrossRef] [PubMed]

42. Baldridge, C.W.; Gerard, R.W. The extra respiration of phagocytosis. Am. J. Physiol. Leg. Content 1932, 103, 235-236. [CrossRef]

43. Cross, A.R.; Segal, A.W. The NADPH oxidase of professional phagocytes-prototype of the NOX electron transport chain systems. Biochim. Biophys. Acta 2004, 1657, 1-22. [CrossRef] [PubMed]

44. Morgan, P.E.; Laura, R.P.; Maki, R.A.; Reynolds, W.F.; Davies, M.J. Thiocyanate supplementation decreases atherosclerotic plaque in mice expressing human myeloperoxidase. Free Radic. Res. 2015, 49, 743-749. [CrossRef]

45. Pattison, D.I.; Davies, M.J.; Hawkins, C.L. Reactions and reactivity of myeloperoxidase-derived oxidants: Differential biological effects of hypochlorous and hypothiocyanous acids. Free Radic. Res. 2012, 46, 975-995. [CrossRef]

46. Furtmüller, P.G.; Burner, U.; Obinger, C. Reaction of Myeloperoxidase Compound I with Chloride, Bromide, Iodide, and Thiocyanate. Biochemistry 1998, 37, 17923-17930. [CrossRef]

47. Davies, M.J.; Hawkins, C.L.; Pattison, D.I.; Rees, M.D. Mammalian heme peroxidases: From molecular mechanisms to health implications. Antioxid. Redox Signal. 2008, 10, 1199-1234. [CrossRef]

48. Pattison, D.I.; Davies, M.J. Absolute rate constants for the reaction of hypochlorous acid with protein side chains and peptide bonds. Chem. Res. Toxicol. 2001, 14, 1453-1464. [CrossRef]

49. Skaff, O.; Pattison, D.I.; Davies, M.J. Hypothiocyanous acid reactivity with low-molecular-mass and protein thiols: Absolute rate constants and assessment of biological relevance. Biochem. J. 2009, 422, 111-117. [CrossRef]

50. Gorman, W.F.; Messinger, E.; Herman, M. Toxicity of thiocyanates used in treatment of hypertension. Ann. Intern. Med. 1949, 30, 1054-1059. [CrossRef]

51. Ruddell, W.S.; Bone, E.S.; Hill, M.J.; Blendis, L.M.; Walters, C.L. Gastric-juice nitrite. A risk factor for cancer in the hypochlorhydric stomach? Lancet 1976, 2, 1037-1039. [CrossRef]

52. Heliovaara, M.; Karvonen, M.J.; Punsar, S.; Rautanen, Y.; Haapakoski, J. Serum thiocyanate concentration and cigarette smoking in relation to overall mortality and to deaths from coronary heart disease and lung cancer. J. Chronic. Dis. 1981, 34, 305-311. [CrossRef]

53. Lijinsky, W.; Kovatch, R.M. Chronic toxicity tests of sodium thiocyanate with sodium nitrite in F344 rats. Toxicol. Ind. Health 1989, 5, 25-29. [CrossRef] [PubMed]

54. Shiue, I. Urinary thiocyanate concentrations are associated with adult cancer and lung problems: USNHANES, 2009-2012. Env. Sci. Pollut. Res. Int. 2015, 22, 5952-5960. [CrossRef]

55. World Health Organization. Global Health Estimates 2016: Disease Burden by Cause, Age, Sex, by Country and by Region, 2000-2016; World Health Organization: Geneva, Switzerland, 2018.

56. Pasceri, V.; Cheng, J.S.; Willerson, J.T.; Yeh, E.T. Modulation of C-reactive protein-mediated monocyte chemoattractant protein-1 induction in human endothelial cells by anti-atherosclerosis drugs. Circulation 2001, 103, 2531-2534. [CrossRef]

57. Ronald, J.A.; Chen, J.W.; Chen, Y.; Hamilton, A.M.; Rodriguez, E.; Reynolds, F.; Hegele, R.A.; Rogers, K.A.; Querol, M.; Bogdanov, A.; et al. Enzyme-sensitive magnetic resonance imaging targeting myeloperoxidase identifies active inflammation in experimental rabbit atherosclerotic plaques. Circulation 2009, 120, 592-599. [CrossRef]

58. Heslop, C.L.; Frohlich, J.J.; Hill, J.S. Myeloperoxidase and C-reactive protein have combined utility for long-term prediction of cardiovascular mortality after coronary angiography. J. Am. Coll. Cardiol. 2010, 55, 1102-1109. [CrossRef]

59. Exner, M.; Hermann, M.; Hofbauer, R.; Hartmann, B.; Kapiotis, S.; Gmeiner, B. Thiocyanate catalyzes myeloperoxidase-initiated lipid oxidation in LDL. Free Radic. Biol. Med. 2004, 37, 146-155. [CrossRef] 
60. Hadfield, K.A.; Pattison, D.I.; Brown, B.E.; Hou, L.; Rye, K.A.; Davies, M.J.; Hawkins, C.L. Myeloperoxidase-derived oxidants modify apolipoprotein A-I and generate dysfunctional high-density lipoproteins: Comparison of hypothiocyanous acid (HOSCN) with hypochlorous acid (HOCl). Biochem. J. 2013, 449, 531-542. [CrossRef]

61. Abdo, A.I.; Rayner, B.S.; van Reyk, D.M.; Hawkins, C.L. Low-density lipoprotein modified by myeloperoxidase oxidants induces endothelial dysfunction. Redox. Biol. 2017, 13, 623-632. [CrossRef]

62. Marsche, G.; Hammer, A.; Oskolkova, O.; Kozarsky, K.F.; Sattler, W.; Malle, E. Hypochlorite-modified high density lipoprotein, a high affinity ligand to scavenger receptor class B, type I, impairs high density lipoprotein-dependent selective lipid uptake and reverse cholesterol transport. J. Biol. Chem. 2002, 277, 32172-32179. [CrossRef] [PubMed]

63. Marsche, G.; Zimmermann, R.; Horiuchi, S.; Tandon, N.N.; Sattler, W.; Malle, E. Class B scavenger receptors CD36 and SR-BI are receptors for hypochlorite-modified low density lipoprotein. J. Biol. Chem. 2003, 278, 47562-47570. [CrossRef] [PubMed]

64. Marsche, G.; Heller, R.; Fauler, G.; Kovacevic, A.; Nuszkowski, A.; Graier, W.; Sattler, W.; Malle, E. 2-Chlorohexadecanal Derived From Hypochlorite-Modified High-Density Lipoprotein-Associated Plasmalogen Is a Natural Inhibitor of Endothelial Nitric Oxide Biosynthesis. Arterioscler. Thromb. Vasc. Biol. 2004, 24, 2302-2306. [CrossRef] [PubMed]

65. Vita, J.A.; Brennan, M.L.; Gokce, N.; Mann, S.A.; Goormastic, M.; Shishehbor, M.H.; Penn, M.S.; Keaney, J.F., Jr.; Hazen, S.L. Serum myeloperoxidase levels independently predict endothelial dysfunction in humans. Circulation 2004, 110, 1134-1139. [CrossRef] [PubMed]

66. Tiyerili, V.; Camara, B.; Becher, M.U.; Schrickel, J.W.; Lütjohann, D.; Mollenhauer, M.; Baldus, S.; Nickenig, G.; Andrié, R.P. Neutrophil-derived myeloperoxidase promotes atherogenesis and neointima formation in mice. Int. J. Cardiol. 2016, 204, 29-36. [CrossRef]

67. Roth Flach, R.J.; Su, C.; Bollinger, E.; Cortes, C.; Robertson, A.W.; Opsahl, A.C.; Coskran, T.M.; Maresca, K.P.; Keliher, E.J.; Yates, P.D.; et al. Myeloperoxidase inhibition in mice alters atherosclerotic lesion composition. PLoS ONE 2019, 14, e0214150. [CrossRef]

68. Brennan, M.L.; Anderson, M.M.; Shih, D.M.; Qu, X.D.; Wang, X.; Mehta, A.C.; Lim, L.L.; Shi, W.; Hazen, S.L.; Jacob, J.S.; et al. Increased atherosclerosis in myeloperoxidase-deficient mice. J. Clin. Investig. 2001, 107, 419-430. [CrossRef]

69. Zoellner, H. Dental infection and vascular disease. Semin. Thromb. Hemost. 2011, 37, 181-192. [CrossRef]

70. Nedoboy, P.E.; Morgan, P.E.; Mocatta, T.J.; Richards, A.M.; Winterbourn, C.C.; Davies, M.J. High plasma thiocyanate levels are associated with enhanced myeloperoxidase-induced thiol oxidation and long-term survival in subjects following a first myocardial infarction. Free Radic. Res. 2014, 48, 1256-1266. [CrossRef]

71. Wang, Z.; Nicholls, S.J.; Rodriguez, E.R.; Kummu, O.; Horkko, S.; Barnard, J.; Reynolds, W.F.; Topol, E.J.; DiDonato, J.A.; Hazen, S.L. Protein carbamylation links inflammation, smoking, uremia and atherogenesis. Nat. Med. 2007, 13, 1176-1184. [CrossRef]

72. Chandler, J.D.; Nichols, D.P.; Nick, J.A.; Hondal, R.J.; Day, B.J. Selective metabolism of hypothiocyanous acid by mammalian thioredoxin reductase promotes lung innate immunity and antioxidant defense. J. Biol. Chem. 2013, 288, 18421-18428. [CrossRef] [PubMed]

73. Zietzer, A.; Niepmann, S.T.; Camara, B.; Lenart, M.A.; Jansen, F.; Becher, M.U.; Andrie, R.; Nickenig, G.; Tiyerili, V. Sodium thiocyanate treatment attenuates atherosclerotic plaque formation and improves endothelial regeneration in mice. PLoS ONE 2019, 14, e0214476. [CrossRef] [PubMed]

74. Xu, Y.; Szep, S.; Lu, Z. The antioxidant role of thiocyanate in the pathogenesis of cystic fibrosis and other inflammation-related diseases. Proc. Natl. Acad. Sci. USA 2009, 106, 20515-20519. [CrossRef] [PubMed]

75. Kantar, A.; Oggiano, N.; Giorgi, P.L.; Braga, P.C.; Fiorini, R. Polymorphonuclear leukocyte-generated oxygen metabolites decrease beat frequency of human respiratory cilia. Lung 1994, 172, 215-222. [CrossRef] [PubMed]

76. Worlitzsch, D.; Herberth, G.; Ulrich, M.; Doring, G. Catalase, myeloperoxidase and hydrogen peroxide in cystic fibrosis. Eur. Respir. J. 1998, 11, 377-383. [CrossRef] [PubMed]

77. Van Der Vliet, A.; Nguyen, M.N.; Shigenaga, M.K.; Eiserich, J.P.; Marelich, G.P.; Cross, C.E. Myeloperoxidase and protein oxidation in cystic fibrosis. Am. J. Physiol. Lung Cell. Mol. Physiol. 2000,279, L537-L546. [CrossRef]

78. Wanner, A.; Salathe, M.; O’Riordan, T.G. Mucociliary clearance in the airways. Am. J. Respir. Crit. Care Med. 1996, 154, 1868-1902. [CrossRef] 
79. Riordan, J.R.; Rommens, J.M.; Kerem, B.; Alon, N.; Rozmahel, R.; Grzelczak, Z.; Zielenski, J.; Lok, S.; Plavsic, N.; Chou, J.L.; et al. Identification of the cystic fibrosis gene: Cloning and characterization of complementary DNA. Science 1989, 245, 1066. [CrossRef]

80. Linsdell, P.; Tabcharani, J.A.; Rommens, J.M.; Hou, Y.X.; Chang, X.B.; Tsui, L.C.; Riordan, J.R.; Hanrahan, J.W. Permeability of wild-type and mutant cystic fibrosis transmembrane conductance regulator chloride channels to polyatomic anions. J. Gen. Physiol. 1997, 110, 355-364. [CrossRef]

81. Frizzell, R.A.; Hanrahan, J.W. Physiology of epithelial chloride and fluid secretion. Cold Spring Harb. Perspect. Med. 2012, 2, a009563. [CrossRef]

82. Conner, G.E.; Wijkstrom-Frei, C.; Randell, S.H.; Fernandez, V.E.; Salathe, M. The lactoperoxidase system links anion transport to host defense in cystic fibrosis. FEBS Lett. 2007, 581, 271-278. [CrossRef] [PubMed]

83. Elkins, M.R.; Robinson, M.; Rose, B.R.; Harbour, C.; Moriarty, C.P.; Marks, G.B.; Belousova, E.G.; Xuan, W.; Bye, P.T.P. A Controlled Trial of Long-Term Inhaled Hypertonic Saline in Patients with Cystic Fibrosis. N. Engl. J. Med. 2006, 354, 229-240. [CrossRef] [PubMed]

84. Konstan, M.W. Therapies aimed at airway inflammation in cystic fibrosis. Clin. Chest Med. 1998, 19, 505-513. [CrossRef]

85. Chandler, J.D.; Min, E.; Huang, J.; McElroy, C.S.; Dickerhof, N.; Mocatta, T.; Fletcher, A.A.; Evans, C.M.; Liang, L.; Patel, M.; et al. Antiinflammatory and Antimicrobial Effects of Thiocyanate in a Cystic Fibrosis Mouse Model. Am. J. Respir. Cell Mol. Biol. 2015, 53, 193-205. [CrossRef] [PubMed]

86. Cegolon, L.; Salata, C.; Piccoli, E.; Juarez, V.; Palu, G.; Mastrangelo, G.; Calistri, A. In vitro antiviral activity of hypothiocyanite against A/H1N1/2009 pandemic influenza virus. Int. J. Hyg. Environ. Health 2014, 217, 17-22. [CrossRef] [PubMed]

87. Gingerich, A.; Pang, L.; Hanson, J.; Dlugolenski, D.; Streich, R.; Lafontaine, E.R.; Nagy, T.; Tripp, R.A.; Rada, B. Hypothiocyanite produced by human and rat respiratory epithelial cells inactivates extracellular H1N2 influenza A virus. Inflamm. Res. 2016, 65, 71-80. [CrossRef]

88. Patel, U.; Gingerich, A.; Widman, L.; Sarr, D.; Tripp, R.A.; Rada, B. Susceptibility of influenza viruses to hypothiocyanite and hypoiodite produced by lactoperoxidase in a cell-free system. PLoS ONE 2018, 13, e0199167. [CrossRef]

89. Kitchens, G.G. Relationship of environmental tobacco smoke to otitis media in young children. Laryngoscope 1995, 105, 1-13. [CrossRef]

90. Jones, L.L.; Hassanien, A.; Cook, D.G.; Britton, J.; Leonardi-Bee, J. Parental Smoking and the Risk of Middle Ear Disease in Children: A Systematic Review and Meta-analysis. Arch. Pediatrics Adolesc. Med. 2012, 166, 18-27. [CrossRef]

91. Yilmaz, G.; Caylan, N.D.; Karacan, C.D. Effects of Active and Passive Smoking on Ear Infections. Curr. Infect. Dis. Rep. 2012, 14, 166-174. [CrossRef]

92. Feldman, C.; Anderson, R. New insights into pneumococcal disease. Respirology 2009, 14, 167-179. [CrossRef] [PubMed]

93. Bates, M.N.; Khalakdina, A.; Pai, M.; Chang, L.; Lessa, F.; Smith, K.R. Risk of tuberculosis from exposure to tobacco smoke: A systematic review and meta-analysis. Arch. Intern. Med. 2007, 167, 335-342. [CrossRef] [PubMed]

94. Lin, H.H.; Ezzati, M.; Murray, M. Tobacco smoke, indoor air pollution and tuberculosis: A systematic review and meta-analysis. PLoS Med. 2007, 4, e20. [CrossRef] [PubMed]

95. Slama, K.; Chiang, C.Y.; Enarson, D.A.; Hassmiller, K.; Fanning, A.; Gupta, P.; Ray, C. Tobacco and tuberculosis: A qualitative systematic review and meta-analysis. Int. J. Tuberc. Lung Dis. 2007, 11, 1049-1061. [PubMed]

96. Gajalakshmi, V.; Peto, R.; Kanaka, T.S.; Jha, P. Smoking and mortality from tuberculosis and other diseases in India: Retrospective study of 43000 adult male deaths and 35000 controls. Lancet 2003, 362, 507-515. [CrossRef]

97. Wang, J.; Shen, H. Review of cigarette smoking and tuberculosis in China: Intervention is needed for smoking cessation among tuberculosis patients. BMC Public Health 2009, 9, 292. [CrossRef]

98. Brunet, L.; Pai, M.; Davids, V.; Ling, D.; Paradis, G.; Lenders, L.; Meldau, R.; van Zyl Smit, R.; Calligaro, G.; Allwood, B.; et al. High prevalence of smoking among patients with suspected tuberculosis in South Africa. Eur. Respir. J. 2011, 38, 139-146. [CrossRef] 
99. Bonacci, R.A.; Cruz-Hervert, L.P.; García-García, L.; Reynales-Shigematsu, L.M.; Ferreyra-Reyes, L.; Bobadilla-del-Valle, M.; Canizales-Quintero, S.; Ferreira-Guerrero, E.; Báez-Saldaña, R.; Téllez-Vázquez, N.; et al. Impact of cigarette smoking on rates and clinical prognosis of pulmonary tuberculosis in Southern Mexico. J. Infect. 2013, 66, 303-312. [CrossRef]

100. Sanz Herrero, F.; Blanquer Olivas, J. Microbiology and risk factors for community-acquired pneumonia. Semin. Respir. Crit. Care Med. 2012, 33, 220-231. [CrossRef]

101. Nuorti, J.P.; Butler, J.C.; Farley, M.M.; Harrison, L.H.; McGeer, A.; Kolczak, M.S.; Breiman, R.F. Cigarette Smoking and Invasive Pneumococcal Disease. N. Engl. J. Med. 2000, 342, 681-689. [CrossRef]

102. Mathe, G.; Gouveia, J.; Hercend, T.; Gros, F.; Dorval, T.; Hazon, J.; Misset, J.L.; Schwarzenberg, L.; Ribaud, P.; Lemaigre, G.; et al. Correlation between precancerous bronchial metaplasia and cigarette consumption, and preliminary results of retinoid treatment. Cancer Detect. Prev. 1982, 5, 461-466. [PubMed]

103. Agius, A.M.; Wake, M.; Pahor, A.L.; Smallman, L.A. Smoking and middle ear ciliary beat frequency in otitis media with effusion. Acta Oto-Laryngol. 1995, 115, 44-49. [CrossRef] [PubMed]

104. Mullen, J.B.; Wright, J.L.; Wiggs, B.R.; Paré, P.D.; Hogg, J.C. Structure of central airways in current smokers and ex-smokers with and without mucus hypersecretion: Relationship to lung function. Thorax 1987, 42, 843-848. [CrossRef] [PubMed]

105. Cecchi, I.; Arias de la Rosa, I.; Menegatti, E.; Roccatello, D.; Collantes-Estevez, E.; Lopez-Pedrera, C.; Barbarroja, N. Neutrophils: Novel key players in Rheumatoid Arthritis. Current and future therapeutic targets. Autoimmun. Rev. 2018, 17, 1138-1149. [CrossRef]

106. Wipke, B.T.; Allen, P.M. Essential role of neutrophils in the initiation and progression of a murine model of rheumatoid arthritis. J. Immunol. 2001, 167, 1601-1608. [CrossRef]

107. Tanaka, D.; Kagari, T.; Doi, H.; Shimozato, T. Essential role of neutrophils in anti-type II collagen antibody and lipopolysaccharide-induced arthritis. Immunology 2006, 119, 195-202. [CrossRef]

108. Eyles, J.L.; Hickey, M.J.; Norman, M.U.; Croker, B.A.; Roberts, A.W.; Drake, S.F.; James, W.G.; Metcalf, D.; Campbell, I.K.; Wicks, I.P. A key role for G-CSF-induced neutrophil production and trafficking during inflammatory arthritis. Blood 2008, 112, 5193-5201. [CrossRef]

109. Odobasic, D.; Yang, Y.; Muljadi, R.C.; O'Sullivan, K.M.; Kao, W.; Smith, M.; Morand, E.F.; Holdsworth, S.R. Endogenous myeloperoxidase is a mediator of joint inflammation and damage in experimental arthritis. Arthritis Rheumatol 2014, 66, 907-917. [CrossRef]

110. Nzeusseu Toukap, A.; Delporte, C.; Noyon, C.; Franck, T.; Rousseau, A.; Serteyn, D.; Raes, M.; Vanhaeverbeek, M.; Moguilevsky, N.; Neve, J.; et al. Myeloperoxidase and its products in synovial fluid of patients with treated or untreated rheumatoid arthritis. Free Radic. Res. 2014, 48, 461-465. [CrossRef]

111. Sur Chowdhury, C.; Giaglis, S.; Walker, U.A.; Buser, A.; Hahn, S.; Hasler, P. Enhanced neutrophil extracellular trap generation in rheumatoid arthritis: Analysis of underlying signal transduction pathways and potential diagnostic utility. Arthritis Res. 2014, 16, R122. [CrossRef]

112. Itoh, Y. Metalloproteinases in Rheumatoid Arthritis: Potential Therapeutic Targets to Improve Current Therapies. Prog. Mol. Biol. Transl. Sci. 2017, 148, 327-338. [CrossRef] [PubMed]

113. Kandasamy, A.D.; Chow, A.K.; Ali, M.A.; Schulz, R. Matrix metalloproteinase-2 and myocardial oxidative stress injury: Beyond the matrix. Cardiovasc. Res. 2010, 85, 413-423. [CrossRef] [PubMed]

114. Fu, X.; Kassim, S.Y.; Parks, W.C.; Heinecke, J.W. Hypochlorous acid oxygenates the cysteine switch domain of pro-matrilysin (MMP-7). A mechanism for matrix metalloproteinase activation and atherosclerotic plaque rupture by myeloperoxidase. J. Biol. Chem. 2001, 276, 41279-41287. [CrossRef] [PubMed]

115. Nagy, P.; Jameson, G.N.; Winterbourn, C.C. Kinetics and mechanisms of the reaction of hypothiocyanous acid with 5-thio-2-nitrobenzoic acid and reduced glutathione. Chem. Res. Toxicol. 2009, 22, 1833-1840. [CrossRef] [PubMed]

116. Costenbader, K.H.; Feskanich, D.; Mandl, L.A.; Karlson, E.W. Smoking intensity, duration, and cessation, and the risk of rheumatoid arthritis in women. Am. J. Med. 2006, 119, 503.e1-503.e9. [CrossRef]

117. Whitehouse, M.W.; Jones, M. Pro-inflammatory activity in rats of thiocyanate, a metabolite of the hydrocyanic acid inhaled from tobacco smoke. Inflamm. Res. 2009, 58, 693-704. [CrossRef]

118. de Brito Rocha, S.; Baldo, D.C.; Andrade, L.E.C. Clinical and pathophysiologic relevance of autoantibodies in rheumatoid arthritis. Adv. Rheumatol. 2019, 59, 2. [CrossRef] 
119. Shi, J.; van Veelen, P.A.; Mahler, M.; Janssen, G.M.; Drijfhout, J.W.; Huizinga, T.W.; Toes, R.E.; Trouw, L.A. Carbamylation and antibodies against carbamylated proteins in autoimmunity and other pathologies. Autoimmun. Rev. 2014, 13, 225-230. [CrossRef]

120. Delporte, C.; Zouaoui Boudjeltia, K.; Furtmuller, P.G.; Maki, R.A.; Dieu, M.; Noyon, C.; Soudi, M.; Dufour, D.; Coremans, C.; Nuyens, V.; et al. Myeloperoxidase-catalyzed oxidation of cyanide to cyanate: A potential carbamylation route involved in the formation of atherosclerotic plaques? J. Biol. Chem. 2018, 293, 6374-6386. [CrossRef]

121. Verheul, M.K.; Fearon, U.; Trouw, L.A.; Veale, D.J. Biomarkers for rheumatoid and psoriatic arthritis. Clin. Immunol. 2015, 161, 2-10. [CrossRef]

122. Shi, J.; Knevel, R.; Suwannalai, P.; van der Linden, M.P.; Janssen, G.M.; van Veelen, P.A.; Levarht, N.E.; van der Helm-van Mil, A.H.; Cerami, A.; Huizinga, T.W.; et al. Autoantibodies recognizing carbamylated proteins are present in sera of patients with rheumatoid arthritis and predict joint damage. Proc. Natl. Acad. Sci. USA 2011, 108, 17372-17377. [CrossRef] [PubMed]

123. Nishida, A.; Inoue, R.; Inatomi, O.; Bamba, S.; Naito, Y.; Andoh, A. Gut microbiota in the pathogenesis of inflammatory bowel disease. Clin. J. Gastroenterol. 2018, 11, 1-10. [CrossRef] [PubMed]

124. Marchal-Bressenot, A.; Salleron, J.; Boulagnon-Rombi, C.; Bastien, C.; Cahn, V.; Cadiot, G.; Diebold, M.D.; Danese, S.; Reinisch, W.; Schreiber, S.; et al. Development and validation of the Nancy histological index for UC. Gut 2017, 66, 43-49. [CrossRef] [PubMed]

125. Buell, M.G.; Berin, M.C. Neutrophil-independence of the initiation of colonic injury. Comparison of results from three models of experimental colitis in the rat. Dig. Dis. Sci. 1994, 39, 2575-2588. [CrossRef] [PubMed]

126. Natsui, M.; Kawasaki, K.; Takizawa, H.; Hayashi, S.I.; Matsuda, Y.; Sugimura, K.; Seki, K.; Narisawa, R.; Sendo, F.; Asakura, H. Selective depletion of neutrophils by a monoclonal antibody, RP-3, suppresses dextran sulphate sodium-induced colitis in rats. J. Gastroenterol. Hepatol. 1997, 12, 801-808. [CrossRef]

127. Chami, B.; San Gabriel, P.T.; Kum-Jew, S.; Wang, X.; Dickerhof, N.; Dennis, J.M.; Witting, P.K. The nitroxide 4-methoxy-tempo inhibits the pathogenesis of dextran sodium sulfate-stimulated experimental colitis. Redox. Biol. 2020, 28, 101333. [CrossRef]

128. Saiki, T.; Mitsuyama, K.; Toyonaga, A.; Ishida, H.; Tanikawa, K. Detection of pro- and anti-inflammatory cytokines in stools of patients with inflammatory bowel disease. Scand. J. Gastroenterol. 1998, 33, 616-622. [CrossRef]

129. Hansberry, D.R.; Shah, K.; Agarwal, P.; Agarwal, N. Fecal Myeloperoxidase as a Biomarker for Inflammatory Bowel Disease. Cureus 2017, 9, e1004. [CrossRef]

130. Mancini, S.; Mariani, F.; Sena, P.; Benincasa, M.; Roncucci, L. Myeloperoxidase expression in human colonic mucosa is related to systemic oxidative balance in healthy subjects. Redox Rep. 2017, 22, 399-407. [CrossRef]

131. Chami, B.; Martin, N.J.J.; Dennis, J.M.; Witting, P.K. Myeloperoxidase in the inflamed colon: A novel target for treating inflammatory bowel disease. Arch. Biochem. Biophys. 2018, 645, 61-71. [CrossRef]

132. Knutson, C.G.; Mangerich, A.; Zeng, Y.; Raczynski, A.R.; Liberman, R.G.; Kang, P.; Ye, W.; Prestwich, E.G.; Lu, K.; Wishnok, J.S.; et al. Chemical and cytokine features of innate immunity characterize serum and tissue profiles in inflammatory bowel disease. Proc. Natl. Acad. Sci. USA 2013, 110, E2332-E2341. [CrossRef] [PubMed]

133. Lakatos, P.L.; Lakatos, L. Risk for colorectal cancer in ulcerative colitis: Changes, causes and management strategies. World J. Gastroenterol. 2008, 14, 3937-3947. [CrossRef] [PubMed]

134. Morgan, P.E.; Pattison, D.I.; Talib, J.; Summers, F.A.; Harmer, J.A.; Celermajer, D.S.; Hawkins, C.L.; Davies, M.J. High plasma thiocyanate levels in smokers are a key determinant of thiol oxidation induced by myeloperoxidase. Free Radic. Biol. Med. 2011, 51, 1815-1822. [CrossRef] [PubMed]

135. Liu, Y.; Burton, T.; Rayner, B.S.; San Gabriel, P.T.; Shi, H.; El Kazzi, M.; Wang, X.; Dennis, J.M.; Ahmad, G.; Schroder, A.L.; et al. The role of sodium thiocyanate supplementation during dextran sodium sulphate-stimulated experimental colitis. Arch. Biochem. Biophys. 2020, 692, 108490. [CrossRef] [PubMed]

(C) 2020 by the authors. Licensee MDPI, Basel, Switzerland. This article is an open access article distributed under the terms and conditions of the Creative Commons Attribution (CC BY) license (http://creativecommons.org/licenses/by/4.0/). 